\title{
Homer Interactions Are Necessary for Metabotropic Glutamate Receptor-Induced Long-Term Depression and Translational Activation
}

\author{
Jennifer A. Ronesi and Kimberly M. Huber \\ Department of Neuroscience, University of Texas Southwestern Medical Center, Dallas, Texas 75390
}

\begin{abstract}
Group I metabotropic glutamate receptors (mGluRs) induce a form of long-term synaptic depression (mGluR-LTD) in area CA1 of the hippocampus that requires rapid protein synthesis. Although much is known about the mechanisms underlying mGluR-LTD, it is unclear how mGluRs couple to the effectors necessary for translation initiation. A clue comes from work in the mouse model of Fragile $\mathrm{X}$ syndrome [Fmr1 knock-out (KO) mice], where group $1 \mathrm{mGluR}$ stimulation of protein synthesis is absent and mGluRs are less associated with the postsynaptic scaffolding protein Homer (Giuffrida et al., 2005). Here, we examined the role of Homer interactions in mGluR-LTD and mGluR signaling to protein synthesis machinery in wild-type and Fmr1 KO animals. A peptide that mimics the C-terminal tail of mGluR5 (mGluR5ct), shown previously to disrupt Homer interactions with mGluRs, blocks mGluR-LTD and mGluR-signaling to protein synthesis initiation in wild-type animals. Disruption of mGluR-Homer interactions selectively blocks mGluR activation of the phosphoinositide 3-kinase (PI3K)-Akt-mammalian target of rapamycin (mTOR), but not ERK (extracellular signal-regulated kinase), pathway and translation of a $5^{\prime}$ terminal oligopyrimidine tract containing mRNA, Elongation factor $1 \alpha$. In Fmr1 K0 mice, mGluR-LTD is insensitive to disruption of Homer interactions and mGluR activation of PI3K-mTOR is lost. Our results find specific roles for Homer in mGluR signaling and plasticity and suggest that reduced mGluR-Homer interactions in Fmr1 KO mice lead to a deficit in mGluR stimulation of translation initiation.
\end{abstract}

Key words: Homer; group I mGluRs; long-term depression; translation; PI3K; mTOR; Fragile X

\section{Introduction}

Brief activation of group I metabotropic glutamate receptors (mGluRs) causes long-term functional changes at synapses via direct regulation of new protein synthesis (Weiler et al., 1997; Huber et al., 2000; Banko et al., 2006; Hou et al., 2006; Mameli et al., 2007; Muddashetty et al., 2007). In the hippocampus, application of the group I mGluR agonist dihydroxyphenylglycine (DHPG) induces a long lasting depression of excitatory synaptic transmission (mGluR-LTD) (Palmer et al., 1997). mGluR-LTD at mature synapses is mediated by a persistent decrease in postsynaptic AMPA receptors and requires synthesis of new proteins (Huber et al., 2000; Snyder et al., 2001). Current evidence indicates that mGluRs activate two signaling pathways which lead to stimulation of translation initiation and are required for LTD, the extracellular signal-regulated kinase (ERK) and phosphoinositide 3-kinase (PI3K)-Akt-mammalian target of rapamycin (mTOR) pathways (Gallagher et al., 2004; Hou and Klann, 2004; Banko et al., 2006).

\footnotetext{
Received Sept. 6, 2007; revised Dec. 4, 2007; accepted Dec. 6, 2007.

This work was supported by National Institutes of Health Grant NS045711 (K.M.H.) and the FRAXA Research Foundation (J.A.R.). K.M.H. is a Southwestern Medical Foundation endowed scholar in biomedical research.

Correspondence should be addressed to Dr. Kimberly M. Huber, Department of Neuroscience, University of Texas Southwestern Medical Center, 5323 Harry Hines Boulevard, NA4.118, Dallas, TX 75390-9011. E-mail: kimberly.huber@utsouthwestern.edu.

DOI:10.1523/JNEUROSCI.5019-07.2008

Copyright $\odot 2008$ Society for Neuroscience $\quad$ 0270-6474/08/280543-05\$15.00/0
}

Homer proteins are postsynaptic scaffolding proteins which bind to the intracellular tail of group $1 \mathrm{mGluRs}$ and are an integral component of the postsynaptic mGluR signaling complex (Brakeman et al., 1997; Xiao et al., 1998; Rong et al., 2003; Mao et al., 2005) (for review, see Duncan et al., 2005). Because of their distinct dimerization properties, long forms of Homer function both as scaffolds of multiprotein complexes and mediators of mGluR signaling. In contrast, short forms of Homer, such as Homer la, lack the dimerization domain and behave as dominant negatives (Xiao et al., 1998). Most relevant here, mGluR interactions with long Homers are required for activation of ERK in striatum and PI3K in hippocampus (Rong et al., 2003; Mao et al., 2005).

MGluR function is altered in the mouse model of human Fragile X syndrome mental retardation, a disorder caused by loss of function mutations in the Fragile $\mathrm{X}$ mental retardation gene Fmr1 (Penagarikano et al., 2007). In Fmr1 knock-out (KO) mice, mGluR-LTD is reportedly enhanced and no longer requires ERK activation or protein synthesis (Huber et al., 2002; Koekkoek et al., 2005; Hou et al., 2006; Nosyreva and Huber, 2006). Paradoxically, mGluR stimulation of rapid protein synthesis is absent in Fmr1 KOs (Todd et al., 2003; Weiler et al., 2004; Hou et al., 2006; Muddashetty et al., 2007). A potential molecular basis for altered mGluR function in Fmrl KOs was suggested by the finding that the group I mGluR, mGluR5, is less associated with long Homer isoforms in these animals (Giuffrida et al., 2005). Here, we acutely disrupted mGluR-Homer interactions using a peptide 
which mimics the Homer binding domain of mGluR 5 to examine the role of Homer interactions in mGluR-signaling to protein synthesis and LTD in wild-type and Fmr1 KO animals.

\section{Materials and Methods}

Slice preparation. Acute hippocampal brain slices $(400 \mu \mathrm{m})$ were prepared from 4 - to 6-week-old Long-Evans hooded rats (Charles River Laboratories, Wilmington, MA), wildtype (WT), or Fmr1 KO C57BL/6 congenic strain) mice as described previously (Volk et al., 2006). For whole-cell experiments, animals were transcardially perfused with dissection buffer before decapitation, and $300 \mu \mathrm{M}$ coronal slices were prepared. CA3 was cut off to avoid epileptogenic activity induced by DHPG. Slices recovered for at least $3 \mathrm{~h}$ at $30^{\circ} \mathrm{C}$ submerged in artificial CSF (ACSF) containing (in mM) 124 $\mathrm{NaCl}, 5 \mathrm{KCl}, 2 \mathrm{CaCl}_{2}, 1 \mathrm{MgCl}_{2}, 26 \mathrm{NaHCO}_{3}$, $1.25 \mathrm{NaH}_{2} \mathrm{PO}_{4}$, and 10 D-glucose, and aerated to $\mathrm{pH}$ 7.4. For whole-cell experiments, slices were maintained in ACSF containing (in $\mathrm{mM}$ ) $126 \mathrm{NaCl}, 3 \mathrm{KCl}, 2 \mathrm{CaCl}_{2}, 1 \mathrm{MgCl}_{2}, 26$ $\mathrm{NaHCO}_{3}, 1.25 \mathrm{NaH}_{2} \mathrm{PO}_{4}, 25$ D-glucose, and 0.025 picrotoxin, aerated to $\mathrm{pH}$ 7.4.

Electrophysiology recordings. For all recordings, slices were submerged and perfused with ACSF at $2.5-3.5 \mathrm{ml} / \mathrm{min}\left(30 \pm 1^{\circ} \mathrm{C}\right)$. Field potentials (FPs) and EPSCs were evoked by stimulation of the Schaffer collateral pathway with a concentric bipolar tungsten electrode. Field potentials were recorded with a glass electrode $(1 \mathrm{M} \Omega)$ filled with ACSF placed in the stratum radiatum of CA1. Test stimuli were delivered every $30 \mathrm{~s}$ and a stable baseline was obtained at $\sim 50 \%$ of the maximum FP amplitude. Whole-cell recordings of CA1 pyramidal neurons were performed as described previously (Huber et al., 2000). Pipettes (3-6 M $\Omega$ ) were filled with (in mM) 134 potassium gluconate, $6 \mathrm{KCl}, 4 \mathrm{NaCl}, 10 \mathrm{HEPES}, 0.2$ EGTA, 4 ATP, 0.3 GTP, and 14 phosphocreatine, $\mathrm{pH}$ 7.2, 295-300 mOsm. Recordings were made from visually identified pyramidal cells in area CA1. Cells were voltage clamped at $-60 \mathrm{mV}$ and the stimulus intensity was set to evoke an EPSC between 200 and 600 pA. Series resistance was $<25 \mathrm{M} \Omega$ and stable throughout the experiment. The group data were analyzed as described previously (Volk et al., 2006). Data plotted in all figures represent average \pm SEM. Significant differences between groups were determined using an independent $t$ test or ANOVA and post hoc Fisher's PLSD (see Fig. 3E, F).

Immunoblotting. As described previously (Gallagher et al., 2004), slices were homogenized in lysis buffer containing $65.2 \mathrm{~mm}$ Tris, $150 \mathrm{~mm} \mathrm{NaCl}, 1 \%$ Triton X-100, 0.1\% SDS, 2 mm EDTA, 50 mm NaH $\mathrm{PO}_{4}, 10$ mm Na4P2O7, protease inhibitor mixture (Calbiochem, San Diego, CA), and phosphatase inhibitor mixtures 1 and 2 (Sigma), at $\mathrm{pH}$ 7.4. Protein concentration was determined using a BCA colorimetric protein assay (Pierce, Rockford, IL), and lysates $(10-40 \mu \mathrm{g})$ were resolved by SDS-PAGE (6-15\%) and transferred to nitrocellulose. Membranes were blocked in 5\% nonfat dry milk and incubated with the following antibodies (Cell Signaling, Danvers, MA, unless otherwise noted) according to the manufacturer's instructions: total-ERK, phospho-ERK (Thr202/Tyr204), total-phosphoinositide-dependent kinase (PDK1), phospho-PDK1 (Ser 241), total-mTOR, phospho-mTOR (Ser2448), phospho-4EBP1 (Thr37/46), phospho-p70S6K (Thr389), elongation factor $1 \alpha(\mathrm{EF} 1 \alpha)$, and Actin (Millipore, Temecula, $\mathrm{CA}$ ) at dilutions of 1:1000-1:5000. Blots were washed and incubated in HRP-conjugated secondary antibody (1:5000; MP Biomedical, Aurora, OH). Bands were detected using enhanced chemiluminescence, and densitometric quantification of immunopositive bands was done using Image J.

\section{Results}

To evaluate group I mGluR-Homer interactions in LTD and signaling, we acutely disrupted mGluR-Homer interactions us- ing a peptide consisting of the mGluR5 C-terminal tail containing the Homer ligand domain, mGluR5ct. This peptide was shown previously to disrupt mGluR-Homer interactions and is made cell permeable by addition of the human immunodeficiency virus-type 1 Tat sequence [tat-mGluRct (CT); YGRKKRRQRRR-ALTPPSPFR] (Mao et al., 2005). Acute disruption may avoid confounds of chronic genetic manipulation of Homer proteins which are known to affect synapse number, mGluR localization and surface expression (for review, see Duncan et al., 2005). Although tat-mGluR5ct reduces mGluR5Homer interactions in neurons, it has no effect on mGluR5 localization, mGluR activation of PLC or increases in intracellular calcium (Mao et al., 2005). Preincubation of rat hippocampal slices with tat-mGluR5ct (CT) $(4-6 \mathrm{~h})$ had no effect on synaptic transmission (as measured with input/output curves) (data not shown), but severely reduced LTD of FPs induced with the group $1 \mathrm{mGluR}$ agonist $R, S$-DHPG $(100 \mu \mathrm{M}, 5 \mathrm{~min})$ (Fig. $1 \mathrm{~A})$ [tatmGluR5ct (CT); $88 \pm 4 \%$ of baseline 50-60 min after DHPG application; $n=8$ ]. LTD values were compared with slices incubated in a peptide with a dual point mutation in the binding motif, which renders the peptide incapable of binding Homer or disrupting mGluR-Homer interactions [tat-mGluR5mu (MU); YGRKKRRQRRR-ALTPLSPRR] (Tu et al., 1998; Mao et al., 2005) (Fig. $1 A$ ) (70 $\pm 4 \% ; n=8$; CT vs MU; $p<0.01)$. Postsynaptic infusion of mGluR5ct (without tat) through a whole-cell patch pipette reduced DHPG-induced LTD (93 $\pm 5 \%$ of baseline 25-30 min after initial DHPG application; $n=10)$, compared with mGluR5mu infused neurons (Fig. 1 B) $(64 \pm 8 \% ; n=9 ; p<$ $0.01)$ indicating that the actions of mGluR5ct are rapid $(30-45$ $\mathrm{min}$ ) and occur in postsynaptic CA1 neurons. The effects of tatmGluR5ct are specific for mGluR-dependent plasticity, as it does not affect NMDAR-dependent LTD induced with low-frequency synaptic stimulation (LFS; $1 \mathrm{~Hz}-900$ pulses) (Fig. 1C) (MU, $83 \pm$ $4 \%$ of baseline $50-60 \mathrm{~min}$ after end of train, $n=6$; CT, $87 \pm 3 \%$, 

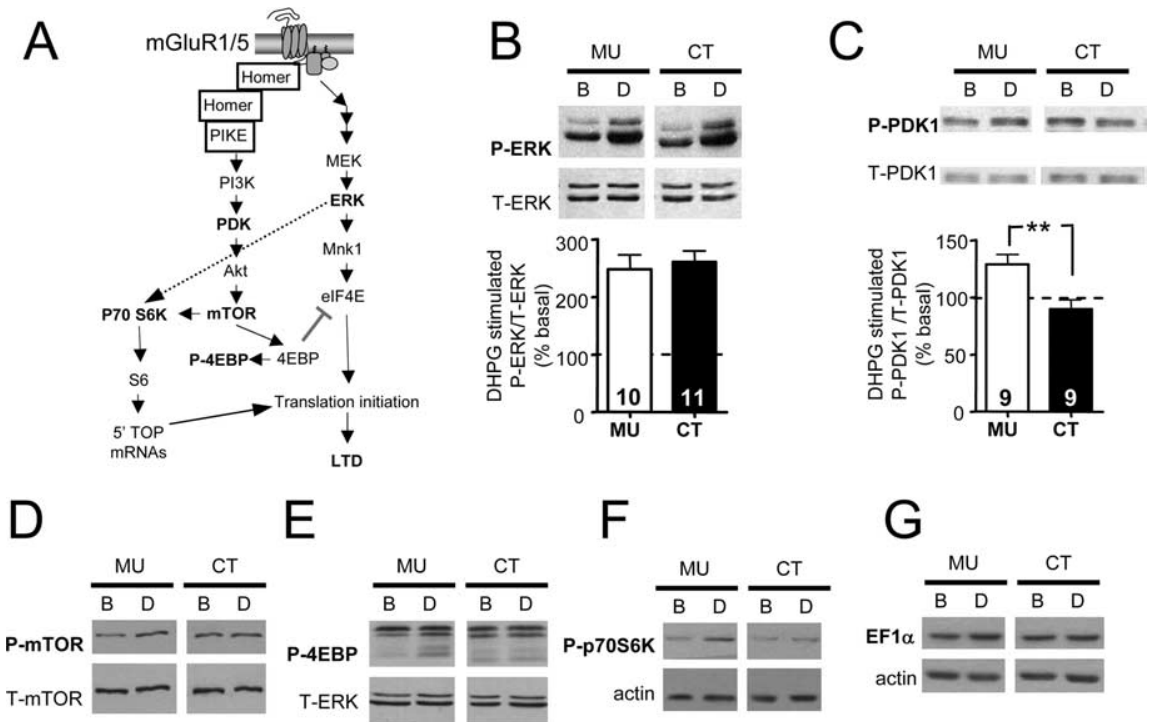

$E$

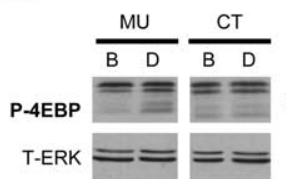

\section{$\mathrm{F}$}
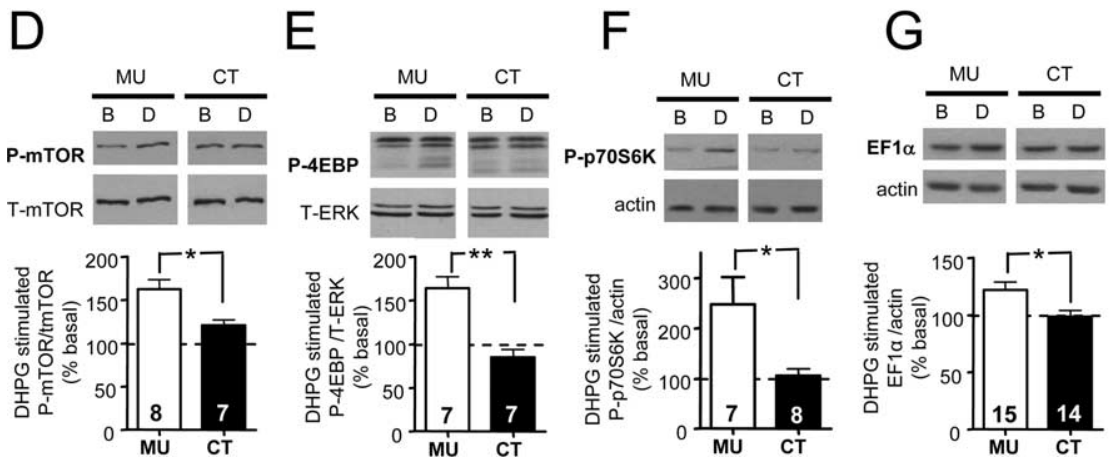

Figure 2. Disruption of mGluR-Homer interactions blocks group I mGluRactivation of the PI3K/mTOR pathway and translation of a $5^{\prime}$ TOP containing mRNA. $A$, Schematic of group I mGluR signaling to protein synthesis machinery via the scaffolding protein Homer. $\boldsymbol{B}-\boldsymbol{F}$, DHPG induced ERK activation is not different in tat-mGluR5ct (CT) and tat-mGluR5mu (MU) treated slices. However, tat-mGluR5ct does impair DHPG-induced phosphorylation of the downstream effectors of PI3K (B), PDK (C), mTOR (D), 4-EBP (E), and p7056K (mTOR site; $\boldsymbol{F}$ ), relative to MU treated slices. G, DHPG-induced upregulation of EF1 $\alpha$ protein is blocked in mGluR5ct treated slices. Top, Representative blots of slices treated with control (MU) or active (CT) peptide during basal (B) and after 5 min DHPG treatment (D). Bottom, Group average of proteins after DHPG treatment for both peptides. The number of slices is on each bar. ${ }^{*} p<0.05 ;{ }^{* *} p<0.01$.

$n=8 ; p>0.05)$. Protein synthesis dependent LTD can also be induced with synaptic stimulation using paired pulse lowfrequency stimulation (PP-LFS; 50 ms interstimulus interval; delivered at $1 \mathrm{~Hz}$ ) (Huber et al., 2000). However, PP-LFS induced LTD can occur independently of NMDA receptors and group 1 mGluRs, but requires M1 muscarinic acetylcholine receptors (Volk et al., 2006, 2007). Tat-mGluR5ct has no effect on PP-LFS induced LTD (in $100 \mu \mathrm{M}$ D,L-AP5) compared with tatmGluR5mu-treated slices (Fig. 1D) (MU, $79 \pm 4 \%$ of baseline $50-60$ min after end of train, $n=7$; CT, $76 \pm 3 \%$; $p>0.05$ ). Together, these data indicate that postsynaptic mGluR-Homer interactions are specifically required for mGluR-dependent LTD.

MGluRs stimulate translation initiation through formation of the eukasyotic initiation factor complex 4F (eIF4F) (Banko et al., 2006). eIF4F complex formation requires phosphorylation of eIF4E-binding protein (4E-BP) via activation of the mTOR pathway and phosphorylation of eIF4E by Mnk, a downstream effector of ERK (Fig. 2A) (Banko et al., 2006). ERK and mTOR also cooperate to activate p70 S6 kinase (p70S6K) which phosphorylates ribosomal protein S6 and stimulates translation of 5' terminal oligopyrimidine tract (5'TOP) containing mRNAs, which typically encode components of the translation machinery (Fig. 2 A) (Dufner and Thomas, 1999). Therefore, tat-mGluR5ct may block LTD because it interferes with mGluR activation of ERK and/or mTOR and stimulation of translation initiation. In striatal neurons, mGluR5 activates ERK, through either phospholipase C (PLC) or long Homer interactions (Mao et al., 2005). In acute hippocampal slices, tat-mGluR5ct had no effect on mGluR- induced activation of ERK in the absence (Fig. $2 B$ ) (MU, $248 \pm 25 \%$ of basal, $n=$ 10 ; CT, $260 \pm 20 \%$ of basal, $n=11 ; p>$ $0.05)$ or presence of a PLC inhibitor (10 $\mu \mathrm{M}$ U73122; MU, $226 \pm 49 \%$ of basal, $n=$ 5; CT, $253 \pm 12 \%, n=6 ; p>0.05)$ In contrast, tat-mGluR5ct specifically blocked mGluR phosphorylation of the PI3K effectors PDK1 (phosphoinositidedependent kinase) (Fig. 2C) (MU, $129 \pm$ $9 \%$ of basal, $n=9$; CT, $90 \pm 8 \%, n=9$; $p<0.01$ ), mTOR (Fig. 2D) (MU, $163 \pm$ $11 \%$ of basal, $n=8$; CT, $121 \pm 6 \%, n=7$; $p<0.01)$, and the translation initiation factor $4 \mathrm{EBP}$ (Fig. $2 \mathrm{E}$ ) (MU, $164 \pm 14 \%$ of basal, $n=7$; CT, $85 \pm 9 \%, n=7$; $p<$ 0.01). In addition, tat-mGluR5ct blocked DHPG induced phosphorylation of p70S6K (Thr 389), at the mTOR site (Fig. $2 F)$ (MU, $203 \pm 42 \%$ of basal, $n=7$; CT, $85 \pm 15 \%, n=8 ; p<0.05)$. TatmGluR5ct incubation alone had no effect on the basal phosphorylation of any protein examined. These results indicate that mGluR-Homer interactions are not generally required for $\mathrm{mGluR}$ signaling in hippocampus, but appear to be specifically important for PI3K and mTORdependent activation of translation initiation, perhaps of $5^{\prime} \mathrm{TOP}$ containing $\mathrm{mR}$ NAs. EF $1 \alpha$ has a $5^{\prime}$ TOP containing mRNA, is localized to dendrites and is rapidly synthesized in response to DHPG (Huang et al., 2005). Consistent with a role for Homer interactions in 5'TOP regulated protein synthesis, preincubation of slices with tatmGluR5ct blocked DHPG-induced increases in EF1 $\alpha$ protein levels (Fig. 2G) (MU, $122 \pm 6 \%$ of basal, $n=15$; CT, $103 \pm 5 \%$ of basal, $n=14 ; p<0.05)$.

Because mGluR-long Homer interactions are reduced in Fmr1 KO mice (Giuffrida et al., 2005), we hypothesized that mGluR activation of the PI3K-mTOR pathway, but not ERK, would be reduced in these mice. Consistent with this hypothesis, DHPG-induced phosphorylation of ERK was normal in Fmr1 KO mice (Fig. 3A) (WT, $288 \pm 28 \%$ of basal, $n=8$; KO, $294 \pm$ $26 \%, n=6 ; p>0.05)$. In contrast, DHPG-induced phosphorylation of the downstream effectors of PI3K, PDK1 (Fig. 3B) (WT, $166 \pm 8$ of basal, $n=4 ; \mathrm{KO}, 113 \pm 15 \%, n=4 ; p<0.05)$, mTOR (Fig. 3C) (WT, $218 \pm 46 \%$ of basal, $n=10$; KO, $103 \pm 12 \%, n=$ $9 ; p<0.05$ ), and p70S6K (Fig. 3D) (WT, $162 \pm 16 \%$ of basal, $n=$ 9; KO, $106 \pm 12 \%, n=11 ; p<0.05)$ were impaired in Fmr1 KO animals. Recent work has reported a deficit in mGluR-induced ERK activation in area CA1 in Fmr1 KOs (Hou and Klann, 2006). To confirm we were measuring mGluR-induced activation of ERK in CA1 selectively, we microdissected the CA1 region after DHPG stimulation and observed ERK activation in both WT and KO mice (WT, $154 \pm 13 \%$ of basal, $n=3 ; \mathrm{KO}, 187 \pm 9 \%$ of basal, $n=3 ; p>0.05)$. There were no differences in the basal phosphorylation state of any protein examined between WT and Fmr1 KO animals (supplemental Table 1, available at www. jneurosci.org as supplemental material).

Although mGluR-Homer complexes are reduced in Fmrl KO mice, mGluR-LTD may still rely on any remaining Homer inter- 
actions. To test this, we examined the sensitivity of mGluR-LTD in Fmr1 KO mice to tat-mGluR5ct. Consistent with our results in rat, the magnitude of mGluR-LTD in WT mice was impaired by tatmGluR5ct (Fig. 3E, G) (MU, $83 \pm 2 \%$ of baseline 50-60 min after initial DHPG application, $n=19$; CT, $92 \pm 1 \%, n=15$; $p=0.006$; Fisher's PLSD). In contrast, DHPG-induced LTD in Fmr1 KO mice is unaffected by tat-mGluR5ct (Fig. $3 F, G$ ) (MU, $82 \pm 3 \%$ of baseline, $n=15$; CT, $81 \pm 3 \%, n=13 ; p=0.73)$. These findings suggest that mGluR-long Homer interactions are reduced to such a level in Fmr1 $\mathrm{KO}$ mice that Homer no longer plays a role in plasticity regulation.

\section{Discussion}

We have shown that Homer interactions are necessary for mGluR-LTD and signaling to translation by linking group I mGluRs to specific downstream targets that regulate protein synthesis initiation. Our data also suggest that reduced mGluR-Homer interactions in Fmrl KOs are responsible for the uncoupling of mGluRs from activation of mTOR and translation initiation. Although mGluRs no longer signal to protein synthesis in Fmrl KO mice, mGluR activation induces LTD which is independent of Homer interactions and protein synthesis. This latter result suggests that the major function of Homer interactions in mGluR-LTD is to activate translation.

Previous work demonstrated a role for Homer in mGluR activation of ERK in striatal cultures using the same mGluR5ct peptide (Mao et al., 2005). Similarly, overexpression of a dominant negative short-form of Homer, Homerla, disrupts mGluR activation of ERK in spinal cord (Tappe et al., 2006). Surprisingly, we find a specific role for Homer interactions in activation of the PI3K-mTOR pathway, but not ERK, in hippocampal neurons, illustrating brain region specific roles for Homer in $\mathrm{mGluR}$ signaling. This finding also demonstrates that acute disruption of Homer interactions in hippocampal neurons does not generally block mGluR function, but may be particularly important for activation of the PI3K pathway. Homer links mGluRs to activation of PI3K via PI3K-enhancer (PIKE), a small GTPase which binds PI3K. When mGluRs are stimulated, an mGluR-Homer-PIKE complex is formed which allows for activation of the lipid kinase activity of PI3 kinase by PIKE (Rong et al., 2003). Our results implicate this complex in mGluR induced LTD and stimulation of translation initiation of 5'TOP containing mRNAs. Consistent with our findings that Homer is selectively required for mGluR stimulation of PI3K-mTOR in wild-type animals, we observed a deficit in activation of the PI3K-mTOR pathway, but not ERK, in response to DHPG in Fmr1 KO mice. Recent work has reported a deficit in mGluR stimulation of ERK in Fmr1 KO mice, using a different DHPG application $(50 \mu \mathrm{M} ; 10 \mathrm{~min})$ than used here (Hou et al., 2006). Therefore, the dose dependence or time course of DHPG induced ERK activation may be affected in Fmr1 KO mice. Our results also suggest that the deficit in mGluR-stimulation of new proteins observed in Fmr1 KO mice is, in part, caused by the disrup-
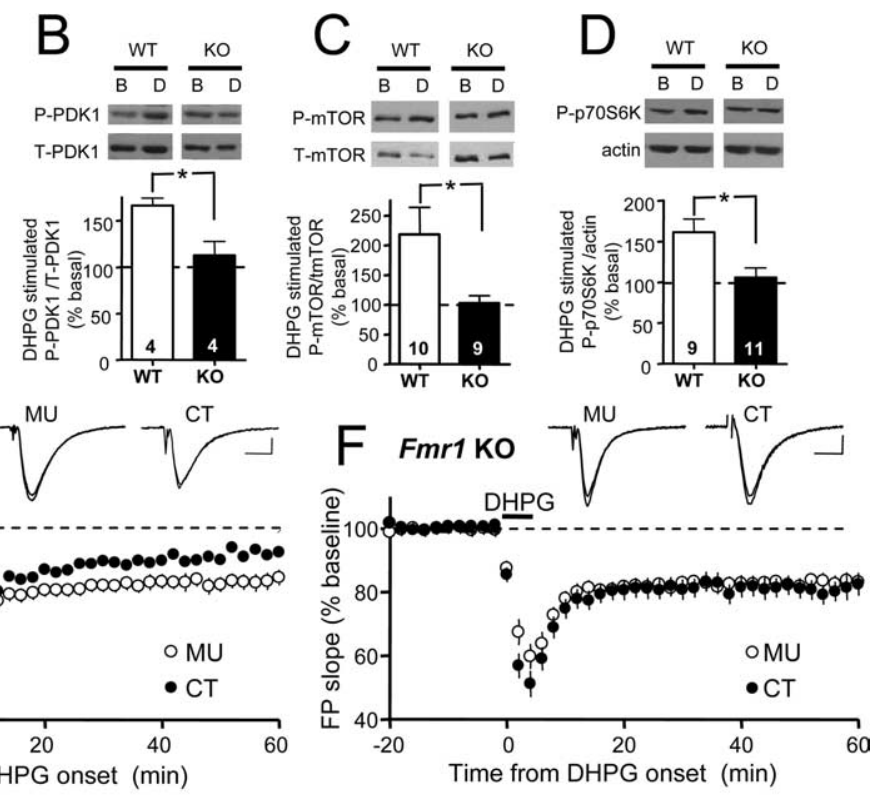

Figure 3. $\quad \boldsymbol{A}-\boldsymbol{D}$, MGluRs fail to activate the PI3K-mTOR pathway and mGluR-LTD is independent of Homer interactions in Fragile X syndrome model, Fmr1 K0 mice. DHPG induces activation of ERK (A), but not PDK1 (B), mTOR (C), and p70S6K in Fmr1 K0 mice Calibration: $0.2 \mathrm{mV}, 7 \mathrm{~ms}$. G, mGluR5ct (CT) inhibits a similar percentage of LTD in both rat and WT mouse slices, but has no effect on LTD in Fmr1 KO slices; ${ }^{* *} p<0.01$. Plotted is the percentage of LTD normalized to LTD values in mGluR5MU-treated slices.

tion of mGluR-Homer interactions and uncoupling of mGluRs from PI3K-mTOR and subsequent translation initiation (Todd et al., 2003; Weiler et al., 2004; Hou et al., 2006; Muddashetty et al., 2007).

Although mGluR-Homer interactions and mGluR signaling to translation initiation is disrupted in Fmr1 KO mice, mGluR-LTD remains intact and is no longer sensitive to mGluR5ct or inhibitors of ERK or protein synthesis (Hou et al., 2006; Nosyreva and Huber, 2006). Despite these differences in induction mechanism, mGluRLTD in both WT and KO animals is expressed as a decrease in surface AMPA receptors (Nosyreva and Huber, 2006). We and others have reported a modest enhancement of mGluR-LTD in Fmr1 KO mice previously (Huber et al., 2002; Koekkoek et al., 2005; Hou et al., 2006; Nosyreva and Huber, 2006). Surprisingly, here we did not observe enhanced DHPG-LTD (Fig. $3 E, F$ ), but a pronounced difference in the ability of the mGluR5ct peptide to affect LTD. Other factors, such as the stress level of the animals or incubation in tatpeptides may affect LTD magnitude and contribute to our inability to observe enhanced mGluR-LTD in Fmr1 KO mice in this study (Chaouloff et al., 2007). Together with our current findings, we suggest a model of mGluR-LTD in Fmr1 KO mice where mGluRs are uncoupled from Homer and the translation initiation machinery which leads to loss of mGluR stimulated protein synthesis. However, because of the loss of translational suppression by Fragile X mental retardation protein, there are dendritic proteins available, at steady 
state, which can be used on mGluR-stimulated AMPA receptor endocytosis to maintain LTD (Nosyreva and Huber, 2006). This model also would predict that Homer interactions are only required for mGluR-LTD to activate translation machinery. Alternatively, in the face of chronic disruption of mGluR-Homer interactions such as those which occur in Fmr1 KO mice, alternative LTD mechanisms may develop which do not require protein synthesis.

Our data (Fig. 3F) and that of Giuffrida et al. (2005) indicate that mGluRs function independently of Homer interactions in Fmr1 KO mice, suggesting that an important mechanism of regulation is lost in Fragile X Syndrome. Homerla, a short Homer isoform, was first discovered as an immediate early gene induced in response to seizures, learning, and experience (Brakeman et al., 1997). Homerla is unable to dimerize with the long, constitutively expressed Homers, but still interacts with mGluRs and other proteins through its EVH1 domain. When induced, Homerla then competes with long Homers and uncouples mGluRs from their effectors (Xiao et al., 1998; Fagni et al., 2002). In support of this idea, Homerla regulates mGluR dependent synaptic plasticity in Xenopus optic tectum and cultured hippocampal neurons (Van Keuren-Jensen and Cline, 2006; Kammermeier and Worley, 2007). In mammals, Homerla induction may function to oppose epilepsy, anxiety, and chronic pain (Tappe et al., 2006) (for review, see Szumlinski et al., 2006). Importantly, in Fmr1 KO mice, mGluRs would be expected to be insensitive to activity-dependent induction of Homerla which may contribute to the epilepsy and anxiety symptoms observed in FXS patients and Fmr1 KO mice (Penagarikano et al., 2007).

\section{References}

Banko JL, Hou L, Poulin F, Sonenberg N, Klann E (2006) Regulation of eukaryotic initiation factor $4 \mathrm{E}$ by converging signaling pathways during metabotropic glutamate receptor-dependent long-term depression. J Neurosci 26:2167-2173.

Brakeman PR, Lanahan AA, O’Brien R, Roche K, Barnes CA, Huganir RL, Worley PF (1997) Homer: a protein that selectively binds metabotropic glutamate receptors. Nature 386:284-288.

Chaouloff F, Hemar A, Manzoni O (2007) Acute stress facilitates hippocampal CA1 metabotropic glutamate receptor-dependent long-term depression. J Neurosci 27:7130-7135.

Dufner A, Thomas G (1999) Ribosomal S6 kinase signaling and the control of translation. Exp Cell Res 253:100-109.

Duncan RS, Hwang SY, Koulen P (2005) Effects of Vesl/Homer proteins on intracellular signaling. Exp Biol Med (Maywood) 230:527-535.

Fagni L, Worley PF, Ango F (2002) Homer as both a scaffold and transduction molecule. Sci STKE 2002:RE8.

Gallagher SM, Daly CA, Bear MF, Huber KM (2004) Extracellular signalregulated protein kinase activation is required for metabotropic glutamate receptor-dependent long-term depression in hippocampal area CA1. J Neurosci 24:4859-4864.

Giuffrida R, Musumeci S, D’Antoni S, Bonaccorso CM, Giuffrida-Stella AM, Oostra BA, Catania MV (2005) A reduced number of metabotropic glutamate subtype 5 receptors are associated with constitutive homer proteins in a mouse model of fragile X syndrome. J Neurosci 25:8908-8916.

Hou L, Klann E (2004) Activation of the phosphoinositide 3-kinase-Aktmammalian target of rapamycin signaling pathway is required for metabotropic glutamate receptor-dependent long-term depression. J Neurosci 24:6352-6361.

Hou L, Antion MD, Hu D, Spencer CM, Paylor R, Klann E (2006) Dynamic translational and proteasomal regulation of fragile $\mathrm{X}$ mental retardation protein controls mGluR-dependent long-term depression. Neuron 51:441-454.

Huang F, Chotiner JK, Steward O (2005) The mRNA for elongation factor lalpha is localized in dendrites and translated in response to treatments that induce long-term depression. J Neurosci 25:7199-7209.

Huber KM, Kayser MS, Bear MF (2000) Role for rapid dendritic protein synthesis in hippocampal mGluR-dependent LTD. Science 288:1254-1257.

Huber KM, Gallagher SM, Warren ST, Bear MF (2002) Altered synaptic plasticity in a mouse model of fragile-X mental retardation. Proc Natl Acad Sci USA 99:7746-7750.

Kammermeier PJ, Worley PF (2007) Homer 1a uncouples metabotropic glutamate receptor 5 from postsynaptic effectors. Proc Natl Acad Sci USA 104:6055-6060.

Koekkoek SK, Yamaguchi K, Milojkovic BA, Dortland BR, Ruigrok TJ, Maex R, De Graaf W, Smit AE, VanderWerf F, Bakker CE, Willemsen R, Ikeda T, Kakizawa S, Onodera K, Nelson DL, Mientjes E, Joosten M, De Schutter E, Oostra BA, Ito M, et al. (2005) Deletion of FMR1 in Purkinje cells enhances parallel fiber LTD, enlarges spines, and attenuates cerebellar eyelid conditioning in Fragile X syndrome. Neuron 47:339-352.

Mameli M, Balland B, Lujan R, Luscher C (2007) Rapid synthesis and synaptic insertion of GluR2 for mGluR-LTD in the ventral tegmental area. Science 317:530-533.

Mao L, Yang L, Tang Q, Samdani S, Zhang G, Wang JQ (2005) The scaffold protein Homerlb/c links metabotropic glutamate receptor 5 to extracellular signal-regulated protein kinase cascades in neurons. J Neurosci 25:2741-2752.

Muddashetty RS, Kelic S, Gross C, Xu M, Bassell GJ (2007) Dysregulated metabotropic glutamate receptor-dependent translation of AMPA receptor and postsynaptic density-95 mRNAs at synapses in a mouse model of fragile X syndrome. J Neurosci 27:5338-5348.

Nosyreva ED, Huber KM (2006) Metabotropic receptor-dependent longterm depression persists in the absence of protein synthesis in the mouse model of fragile X syndrome. J Neurophysiol 95:3291-3295.

Palmer MJ, Irving AJ, Seabrook GR, Jane DE, Collingridge GL (1997) The group I mGlu receptor agonist DHPG induces a novel form of LTD in the CA1 region of the hippocampus. Neuropharmacology 36:1517-1532.

Penagarikano O, Mulle JG, Warren ST (2007) The Pathophysiology of Fragile X Syndrome. Annu Rev Genomics Hum Genet 8:109-129.

Rong R, Ahn JY, Huang H, Nagata E, Kalman D, Kapp JA, Tu J, Worley PF, Snyder SH, Ye K (2003) PI3 kinase enhancer-Homer complex couples mGluRI to PI3 kinase, preventing neuronal apoptosis. Nat Neurosci 6:1153-1161.

Snyder EM, Philpot BD, Huber KM, Dong X, Fallon JR, Bear MF (2001) Internalization of ionotropic glutamate receptors in response to mGluR activation. Nat Neurosci 4:1079-1085.

Szumlinski KK, Kalivas PW, Worley PF (2006) Homer proteins: implications for neuropsychiatric disorders. Curr Opin Neurobiol 16:251-257.

Tappe A, Klugmann M, Luo C, Hirlinger D, Agarwal N, Benrath J, Ehrengruber MU, During MJ, Kuner R (2006) Synaptic scaffolding protein Homerla protects against chronic inflammatory pain. Nat Med 12:677-681.

Todd PK, Mack KJ, Malter JS (2003) The fragile X mental retardation protein is required for type-I metabotropic glutamate receptor-dependent translation of PSD-95. Proc Natl Acad Sci USA 100:14374-14378.

Tu JC, Xiao B, Yuan JP, Lanahan AA, Leoffert K, Li M, Linden DJ, Worley PF (1998) Homer binds a novel proline-rich motif and links group 1 metabotropic glutamate receptors with IP3 receptors. Neuron 21: 717-726.

Van Keuren-Jensen K, Cline HT (2006) Visual experience regulates metabotropic glutamate receptor-mediated plasticity of AMPA receptor synaptic transmission by homerla induction. J Neurosci 26:7575-7580.

Volk LJ, Daly CA, Huber KM (2006) Differential roles for group 1 mGluR subtypes in induction and expression of chemically induced hippocampal long-term depression. J Neurophysiol 95:2427-2438.

Volk LJ, Pfeiffer BE, Gibson JR, Huber KM (2007) Multiple Gq-coupled receptors converge on a common protein synthesis-dependent long-term depression that is affected in fragile $\mathrm{X}$ syndrome mental retardation. J Neurosci 27:11624-11634.

Weiler IJ, Irwin SA, Klintsova AY, Spencer CM, Brazelton AD, Miyashiro K, Comery TA, Patel B, Eberwine J, Greenough WT (1997) Fragile X mental retardation protein is translated near synapses in response to neurotransmitter activation. Proc Natl Acad Sci USA 94:5395-5400.

Weiler IJ, Spangler CC, Klintsova AY, Grossman AW, Kim SH, BertainaAnglade V, Khaliq H, de Vries FE, Lambers FA, Hatia F, Base CK, Greenough WT (2004) Fragile X mental retardation protein is necessary for neurotransmitter-activated protein translation at synapses. Proc Natl Acad Sci USA 101:17504-17509.

Xiao B, Tu JC, Petralia RS, Yuan JP, Doan A, Breder CD, Ruggiero A, Lanahan AA, Wenthold RJ, Worley PF (1998) Homer regulates the association of group 1 metabotropic glutamate receptors with multivalent complexes of homer-related, synaptic proteins. Neuron 21:707-716. 